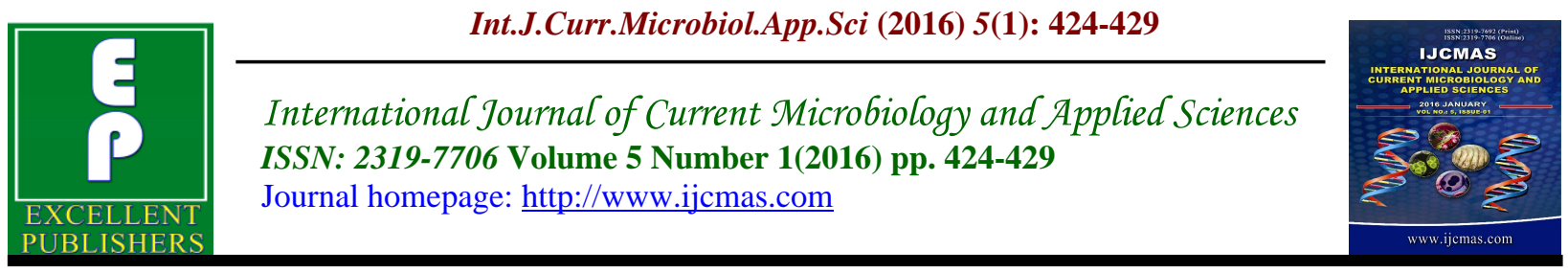

Original Research Article

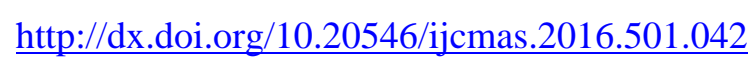

\title{
A Regulatory/ Signaling Molecule of Group A Streptococci (GAS) May be Responsible for Modulation of Bacterial Virulence
}

\author{
Bindu Arora*, Anupama Rao and Chinmaya Kashikar \\ Department of Biotechnology, Abasaheb Garware College, Karve Road, Pune-411 004, India \\ *Corresponding author
}

\section{A B S T R A C T}

Keywords

Extracellular amylase, Group A Streptococci, Beta haemolysis

\section{Article Info}

\section{Accepted:}

18 December 2015

Available Online:

10 January 2016
Pathogenic microbes secrete various enzymes to facilitate their survival within the host which may have direct/ indirect role to play in bacterial virulence. In the present work, extracellular amylase producing bacteria were isolated from air, water and soil samples by serial dilution and plating method. Twenty three bacterial isolates obtained were screened for amylolytic activity, out of which only 5 isolates showed amylolytic activity viz: Streptococcus sp., Staphylococcus sp., two Bacillus sp. and Veillonella sp., which were identified by phenotypic characterization. The results revealed that Streptococcus sp. exhibit beta haemolysis on blood agar and had the potential to produce 120 EU extracellular amylase after 48 hours. This is reported here for the first time for production of extracellular amylase. This enzyme might be a regulatory/ signaling molecule and thus be an attractive drug target in the treatment of bacterial infections.

\section{Introduction}

Human pathogenic bacteria produce various extracellular factors including enterotoxin, hemolysin, cytotoxin, protease, collagenase, phospholipase, siderophore, and hemagglutinin. Of these factors, enterotoxin, hemolysin and cytotoxin are directly related to the clinical symptoms, however siderophore and hemagglutinin may have a role to play in the establishment of the infection (Mitchell, 2003; Janda, et al., 1988). Also fungal plant pathogens are known to produce extracellular enzymes that cleave virtually every glycosidic linkages in plant cell wall polysaccharides.
The polysaccharides present in the environment of the pathogen regulate the growth of the microorganisms and the enzymes produced (Shambe, 1982). Extracellular enzymes, including serine protease, chitinase and collagenase have been reported to be involved in the infectious process as virulence factors in nematodes (Huang, et al., 2004). Extracellular lipases and phospholipases have evidences in contribution to the virulence of pathogenic fungi like Candida albicans and Cryptococcus neoformans. 
They have been also shown to influence growth, morphology, adherence and dissemination of fungal cells across the host (Park et al., 2013).

Group A Streptococci (GAS) have been reported to cause various diseases like pharyngitis (Wannamaker et al., 1951) scarlet fever (rash), impetigo (infection of the superficial layers of the skin) (Bisno and Stevens, 1996) or cellulitis (infection of the deep layers of the skin) (Stevens et al., 1994). Invasive, toxigenic infections can result in necrotizing fasciitis, myositis and streptococcal toxic shock syndrome (Stevens, 1995; Cunningham,2000). However the pattern changes with time and varies from place to place (Mitchell, 2003). Virulence factors of $S$. pyogenes Group A (GAS) potentially cause a large number of diseases because of variety of virulence factors present in them which include $M$ protein, fibronectin-binding protein (Protein F) and lipoteichoic acid for adherence, invasins such as streptokinase, streptodornase (DNase B), hyaluronidase, and streptolysins, exotoxins such as pyrogenic (erythrogenic) toxin (Cunningham, 2000; Metzgar and Zampolli, 2011). The $S$. pyogenes Group A (GAS) capsule is composed of a polymer of hyaluronic acid containing repeating units of glucuronic acid and $N$-acetylglucosamine and is required for resistance to phagocytosis (Wessels and Bronze 1994). Terao Y (2012) has reported that $S$. pyogenes is equipped with a wide variety of virulence factors which includes surfacelocated fibronectin-binding proteins (FbaA and $\mathrm{FbaB}$ ), major invasion molecule, bacterial cysteine protease (SpeB) and a C6binding protein in cell-surface protein fraction.

In the present study, we report the production of extracellular amylase by $S$. pyogenes and propose its function in the utilization of carbohydrates as well as establishing infection.

\section{Materials and Methods}

Soil, air and water were screened for bacterial isolates secreting extracellular enzyme amylase for which 23 colonies were picked and isolated. Total five bacterial isolates could produce amylase on starch agar plate assay (Fig 1). These isolates were characterized on the basis of colony morphology, microscopic characters, endospore formation, presence of capsule and biochemical tests viz: Indole, methyl red, Voges-Proskaeur, Simmons citrate test, gelatin hydrolysis test, oxidase test and catalase test (Holt et al., 1994; Koneman et al., 1997).

\section{Results and Discussion}

Isolate 1 (BT1) showed circular, small, translucent, dark creamy to light orange coloured colonies with entire margin without pigmentation. It was gram-negative cocci, present singly or as diplococci and was non motile. It did not have endospore, was non-capsulated, VP and catalase positive. It was indole, MR and citrate negative and unable to ferment glucose, sucrose, lactose and mannitol showing very unusual metabolism. As reported earlier, Veillonella were characterized by their unusual metabolism as they are unable to ferment carbohydrates including glucose but grow well anaerobically on lactate, pyruvate, malate or fumarate (Kolenbrander, 2006).

Isolates BT4 and BT5 were large, wide, gram-positive rods, facultative anaerobe, often occur singly or in pairs and can produce endospores. They were found to be catalase-positive, indole positive, VP 
positive, utilized citrate as source of carbon, urease positive, showed acid production from glucose and sucrose. They were motile with sub terminal endospore and did not produce capsule suggesting to be considered as Bacillus spp. Colony morphology of Bacillus spp. was highly variable, often growing as round opaque colonies on nutrient agar medium with sticky consistency.

Isolate BT3 was gram-positive cocci found in clusters, was not motile, did not produce endospores and capsule. Staphylococcus sp. was catalase-positive, oxidase negative, VP positive, utilized citrate as source of carbon, showed acid production from glucose and sucrose. Colony morphology of Staphylococcus sp. grew as pinpoint creamy white with entire margin and opaque colonies on nutrient agar medium with no pigmentation. When grown on blood agar it did not show haemolysis. As known, biochemically Staphylococcus produced catalase that degrade hydrogen peroxide whereas Streptococci did not (Holt et al., 1994).

Isolate BT2 was gram-positive, non-motile, non-spore forming coccus that occur in chains or in pairs of cells. Individual cells were round-to-ovoid cocci. Streptococci divided in one plane and occurred in pairs or in chains of varying lengths. The metabolism of BT2 was fermentative, the organism was catalase-negative. It was found to be aero tolerant anaerobe (facultative anaerobe) and was capsulated. Based on Bergey's Manual of Determinative Bacteriology the isolates were identified as Veillonella sp.(BT1), Streptococcus sp.(BT2), Staphylococcus sp. (BT3) and two Bacillus spp.(BT 4, BT 5) (Holt et al., 1994; Koneman et al., 1997).

The strain showing maximum zone of inhibition in starch hydrolysis test was found to be Streptococcus sp. and therefore further characterized using blood agar (enriched medium). It exhibited beta (clear) hemolysis on blood agar showing complete lysis of red blood cells in the medium (Fig 2). The complete haemolysis on blood agar and other bio chemicals suggested it to be $S$. pyogenes Group A (GAS).

Soil, air and water samples contained different microorganisms and found to be potential sources of various useful enzymes. Among different types of enzymes obtained from microbial sources, amylases are the most widely used in industry. In the previous studies, dental caries by $S$. mutans arose as a consequence of metabolism of dietary carbohydrates (Mitchell, 2003) and also utilization of starch by $S$. mutans was dependent on the addition of exogenous $\alpha$ amylase ( Simpson and Russell, 1998). It had been reported that Bacillus sp. as the potent source of amylases (Roy et al., 2012; Najafi et al., 2005), however, in our results we got pathogenic Streptococcus sps. more potent amylase producer than the isolated Bacillus spps. The results showed that $S$. pyogenes Group A (GAS) had the potential to produce $120 \mathrm{EU}$ extracellular amylase in 48 hours by DNSA method of quantification. Other carbohydrates like $2 \%$ maltose and $2 \%$ sucrose were also used instead of starch (Freer, 1993) but they did not induced extracellular amylase production. One unit of amylase (EU) EC 3.2.1.2 was defined as the amount of enzyme that releases $1 \mu$ mole of reducing sugar as glucose per min under the assay conditions (Plummer, 1978). This enzyme production might be attributed for obtaining nutrients via digestion of carbohydrate substrate. Further the role of extracellular enzymes secretion in modulation of bacterial virulence cannot be neglected. 
In previous studies, Walker GJ (1965) had isolated the cell-bound alpha-amylase of $S$. bovis by chromatography on DEAEcellulose. Christine L. Simpson and Roy R. B. Russell (1998) deduced amino acid sequence by showed a strong similarity (60\% amino acid identity) to the intracellular $\alpha$-amylase of Streptococcus bovis. Whitehead TR and Cotta MA (1995) identified intracellular amylase activity in $S$. bovis and $S$. salivarius. SN Freer (1993) purified and characterized extracellular alpha-amylase from $S$. bovis JB1. However, the extracellular amylases have not been reported till now by $S$. pyogenes Group A (GAS).

It has been reported that certain pathogens secrete extracellular enzymes which were involved in the infectious process as virulence factors. S. pyogenes Group A (GAS) infections were caused using a wide variety of virulence factors which includes bacterial cysteine protease, SpeB and C6binding protein, a cell-surface protein and FbaA and FbaB surface located proteins as major invasion molecules (Terao,2012). Since various regulatory and signaling molecules were attractive drug targets in the treatment of bacterial infections thus understanding signaling responses of $S$. pyogenes Group A (GAS) was essential for elucidation of pathogenesis of $S$. pyogenes Group A (GAS) infection and for the identification of novel therapeutic agents.

Fig.1 Zone of Clearance due to the Hydrolysis of Starch

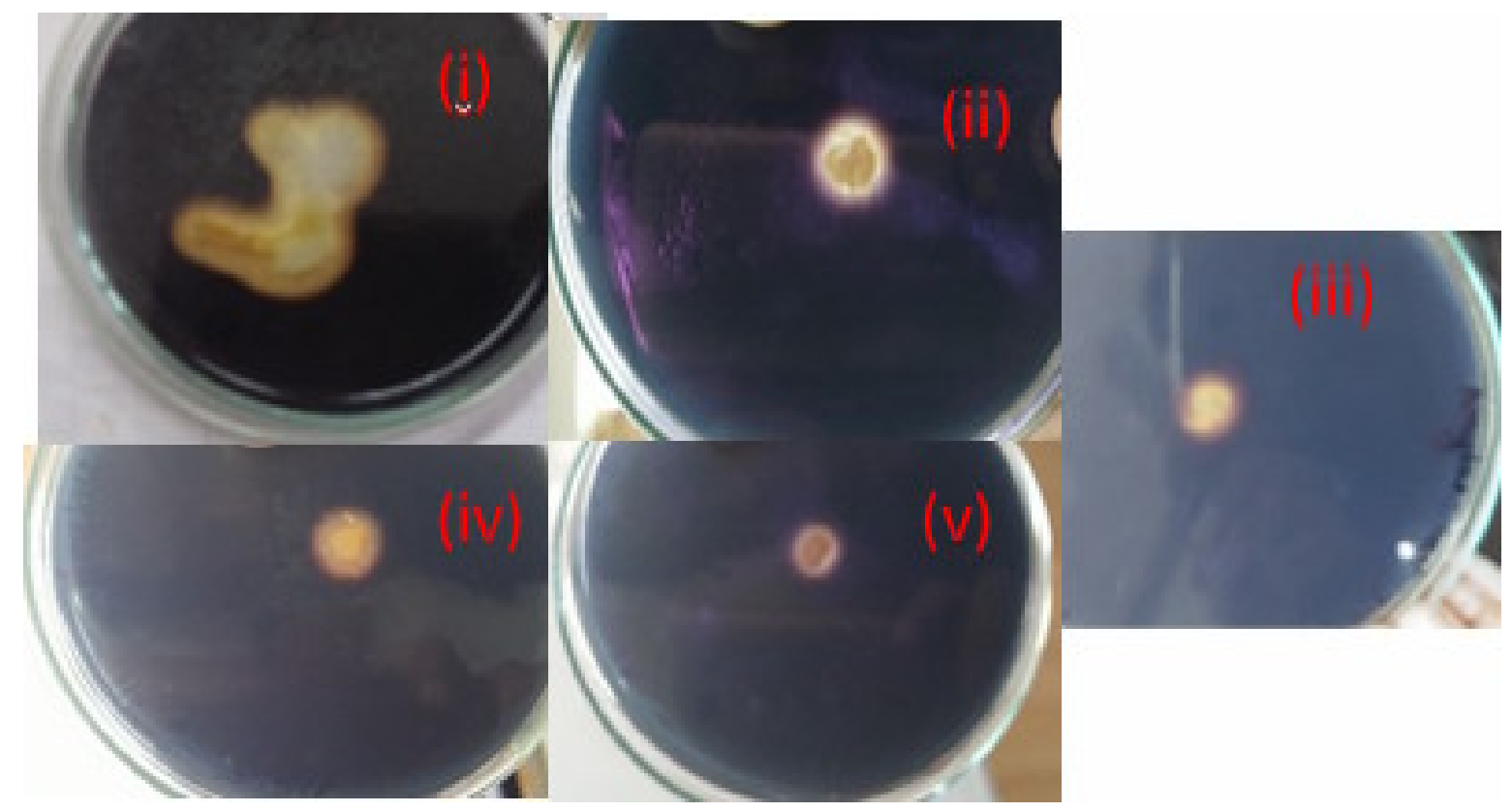

Fig.1 Zone of Clearance due to the Hydrolysis of Starch. Screening of five isolates (i to v) for capability of amylase production (plate assay method). Isolates were spot innoculated/ streaked in the center on the starch agar plate and plates were incubated at $37^{\circ} \mathrm{C}$ for $24 \mathrm{~h}-48 \mathrm{~h}$. After incubation iodine solution was flooded on the starch agar plate for 30 seconds. Presence of clear zone of hydrolysis around the bacterial growth indicates positive result and isolates were considered as amylase producers. 
Fig.2 Blood Agar Test

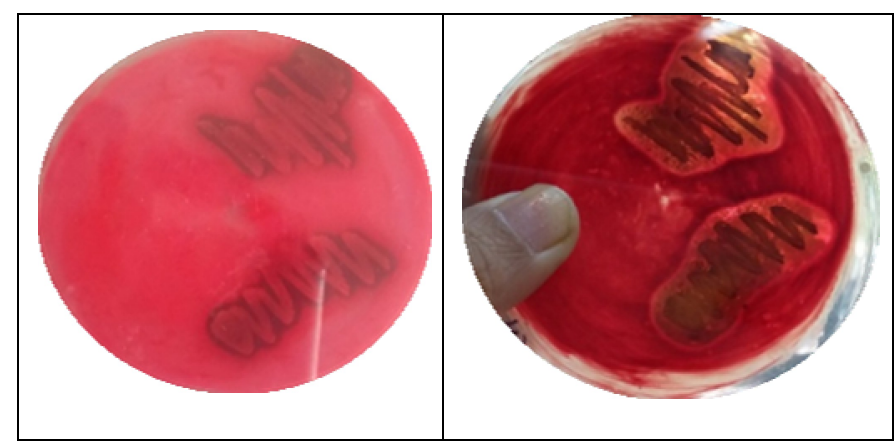

Fig.2 Blood Agar Test: When streaked on Blood Agar, Streptococcus sp. cause hemolysis i.e., destruction of the erythrocytes (and hemoglobin) in the medium. The colony is surrounded by a white or clear zone in which few or no intact erythrocytes are found. Zone of haemolysis observed after 24 hours (i) and after 48 hours (ii).

The amylase production by $S$. pyogenes Group A in considerable amounts with considerable certainty may have links with its pathogenicity (stress survival) or nutrition or both which is further an indication that this extracellular protein may have potential to be developed as a vaccine target.

The findings of the paper has possibility of facilitating the discovery of new compound (regulatory/ signaling molecule) which may have a greater role to play in modulation of bacterial virulence and thus may pave the path for further research leading to attractive drug targets in the treatment of bacterial infections.

\section{Acknowledgement}

The authors would like to thank Principal, MES Abasaheb Garware College, Pune for chemicals and lab support. Thanks to Phadtare S' Kharote B and Dhondepurge A for necessary support.

\section{Compliance with Ethical Standards}

Authors declare that they have no conflict of interest. This article does not contain any studies with human participants or animals performed by any of the authors.

\section{References}

Bisno, A.L., Stevens, D.L., 1996. Streptococcal infections in skin and soft tissues. N Engl J Med 334:240-245.

Brooker, J.D., McCarthy, J.M.,1997. Gene knockout of the intracellular amylase gene by homologous recombination in Streptococcus bovis. Curr Microbiol 35(3): 133-138

Christine, L. Simpson. and Roy, R. B. Russell.,1998. Intracellular $\alpha$-Amylase of Streptococcus mutans J Bacteriol. 180(17): 4711-4717

Cunningham, M.W., 2000. Pathogenesis of Group A Streptococcal Infections. Clin Microbiol Rev 13(3): 470-511. doi: 10.1128/CMR.13.3.470-511

Freer, S.N., 1993. Purification and characterization of the extracellular alphaamylase from Streptococcus bovis JB. Appl Environ Microbiol. 59(5):1398-402

Holt, J.G., Krieg, N.R., Sneath, P.H.A., Staley, J.T., Williams, S.T., 1994. editors. Bergey's Manual of Determinative Bacteriology. 9th ed. Baltimore: Williams and Wilkins; p. 559

Huang, X., Zhao, N., Zhang, K., 2004. Extracellular enzymes serving as virulence factors in nematophagous fungi involved in 
infection of the host. Res Microbiol, 155(10):811-6.

Janda, J.M., Power, C., Bryant, R.G., Abbott, S.L. 1988. Current perspectives on the epidemiology and pathogenesis of clinically significant Vibrio spp. Clin Microbiol Rev 1: 245-267. PMID: 3058295

Kolenbrander, P., 2006. The Prokaryotes, The Genus Veillonella Springer 4: 1022-1040.

Koneman, E.W., Allen, S.D., Janda, W.M., Schreckenberger, P.C., Winn, W.J., 1997. editors. Color Atlas and Textbook of Diagnostic Microbiology. 5th ed. Philadelphia: Lippincott Williams and Wilkins; p. 651-708

Metzgar,D., Zampolli, A. 2011. The M protein of group A Streptococcus is a key virulence factor and a clinically relevant strain identification marker. Virulence 2(5):40212.

Mitchell, T.J., 2003. The pathogenesis of streptococcal infections: from Tooth decay to meningitis. Nature Reviews Microbiology 1: 219-230

Najafi, M.F., Deobagkar, D., Deobagkar, D., 2005. Purification and characterization of an extracellular alpha-amylase from Bacillus subtilis AX20. Protein Expr Purif 41(2):349-54

Park, M., Do, E., Hee, Jung. W., 2013. Lipolytic Enzymes Involved in the Virulence of Human Pathogenic Fungi. Mycobiology 41(2): 67-72. doi: 10.5941/MYCO.2013.41.2.67

Plummer, D.T., 1978. An Introduction to Practical Biochemistry, Second edition, McGraw Hill.

Roy, J.K., Rai, S.K., Mukherjee, A.K., 2012. Characterization and application of a detergent-stable alkaline $\alpha$-amylase from Bacillus subtilis strain AS-S01a. Int J Biol
Macromol. 50(1):219-29. doi: 10.1016/ j.ijbiomac.2011.10.026. Epub 2011 Nov 6.

Shambe, T., 1982. Production of extracellular amylase and hemicellulase from four fungal pathogens. Carbohydrate Research 110:176 $-180$

Simpson, C.L., Russell, R.R.B.,1998. Intracellular $\alpha$-Amylase of Streptococcus mutans. J Bacteriol 180(17): 4711-4717. PMCID: PMC107487

Stevens, D.L., Bryant, A.E., Yan, S., 1994. Invasive group A streptococcal infection: new concepts in antibiotic treatment. Int $\mathbf{J}$ Antimicrob Agents 4:297-301

Stevens, D.L., 1995. Streptococcal toxic shock syndrome: Spectrum of disease, pathogenesis and new concepts in treatment. Emerg Infect Dis 1:69-78

Terao, Y., 2012. The virulence factors and pathogenic mechanisms of Streptococcus pyogenes. 54(2):96-100.

Walker, G.J., 1965. The cell-bound alphaamylases of Streptococcus bovis. Biochem J 94:289-98

Wannamaker, L.W., Rammelkamp, C.H. Jr., Denny, F.W., Brink, W.R., Houser, H.B., Hahn, E.O., Dingle, J.H., 1951. Prophylaxis of acute rheumatic fever by treatment of the preceding streptococcal infection with various amounts of depot penicillin. Am J Med 10:673-95

Wessels, M.R., Bronze, M.S., 1994. Critical role of the group A streptococcal capsule in pharyngeal colonization and infection in mice. Proc Natl Acad Sci USA 91:1223812242

Whitehead, T.R., Cotta, M.A., 1995. Identification of intracellular amylase activity in Streptococcus bovis and Streptococcus salivarius. Curr Microbiol 30(3):143-8.

\section{How to cite this article:}

Bindu Arora, Anupama Rao and Chinmaya Kashikar. 2016. A Regulatory/ Signaling Molecule of Group A Streptococci (GAS) May be Responsible for Modulation of Bacterial Virulence.

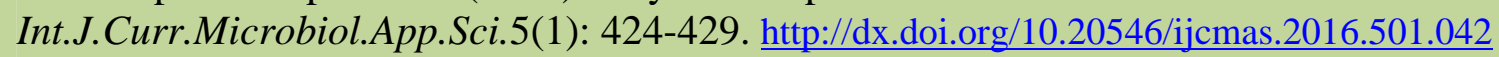

